\title{
Combining diagnostic procedures for the management of leishmaniasis in areas with high prevalence of Leishmania guyanensis
}

\section{Procedimentos diagnósticos combinados no manejo da leishmaniose em áreas com alta prevalência de Leishmania guyanensis}

\author{
Ednelza de Almeida Benicio ${ }^{1}$ \\ Ellen Pricilla Nunes Gadelha ${ }^{1}$ \\ Anette Talhari ${ }^{1}$ \\ Roberto Moreira da Silva $\mathrm{Jr}^{1}$ \\ Luis Carlos Ferreira ${ }^{1}$ \\ Mayara Cristina Cordeiro dos Santos ${ }^{2}$
}

\author{
Marcelo Távora Mira ${ }^{2}$ \\ Cintia Mara Costa de Oliveira ${ }^{3}$ \\ Carolina Talhari ${ }^{4}$ \\ Sinésio Talhari5 \\ Paulo Roberto Machado ${ }^{6}$ \\ Albert Schriefer ${ }^{6}$
}

\begin{abstract}
BACKGROUnD: The Amazon region corresponds to approximately $40 \%$ of the cases of leishmaniasis in Brazil. We report a prospective study with 180 patients conducted in a health care unit that diagnoses $10 \%$ of the cases of leishmaniasis in the Brazilian Amazon. The study addresses how a combination of procedures improves diagnosis in areas with high prevalence of Leishmania guyanensis.

ОвјестіVEs: to evaluate diagnostic methods in areas with high prevalence of Leishmania guyanensis.

MeтHODS: All subjects were amastigote-positive by direct microscopic examination of lesion scarifications. We conducted skin biopsy and histopathology, polymerase chain reaction and parasite cultivation.

RESULTS: Polymerase chain reaction detected almost ninety percent of infections when two amplification protocols were used (mini-exon and HSP-70). HSP-70 specific polymerase chain reaction matched the sensitivity of parasite cultivation plus histopathology.

CONCLUSION: The best combination was polymerase chain reaction plus histopathology, which increased diagnostic sensitivity to $94 \%$. Species discrimination by polymerase chain reaction disclosed prevalence of human infections with Leishmania guyanensis of $94 \%$ and with Leishmania braziliensis of $6 \%$ for this region.
\end{abstract}

Keywords: Diagnosis; Leishmania guyanensis; Leishmaniasis

Resumo: FunDAMENTOS: O Amazonas corresponde a aproximadamente 40\% dos casos de leishmaniose do país. Nós reportamos um estudo prospectivo com 180 pacientes de uma unidade de saúde que diagnostica $10 \%$ dos casos de leishmaniose da amazônia brasileira, com combinação de métodos diagnóstico em área de alta prevalência de Leishmania guyanensis.

Oвјетіvos: avaliar métodos diagnóstico da Leishmaniose em área endêmica para Leishmania Amazonensis.

MéTodos: Todos os pacientes tiveram exame direto positivo com presença de amastigotas. Foi feita também biópsia cutânea, com realização de exame histológico, reação em cadeia da polimerase e cultura.

RESULTADO: A reação em cadeia da polimerase detectou aproximadamente $90 \%$ de infecção quando foram usados duas técnicas de amplificação (mini-exon and HSP-70). A reação em cadeia da polimerase com HSP-70 foi mais sensível que a cultura associada à histopatologia.

CONCLUSÃo: A melhor combinação foi a reação em cadeia da polimerase com histopatologia, com sensibilidade de $94 \%$. A discrimanação das espécies causadoras de infecção humana nessa região mostrou Leishmania guyanensis em $94 \%$ dos casos e Leishmania brasiliensis em $6 \%$.

Palavras-chave: Diagnóstico; Leishmania guyanensis; Leishmaniose

Received on 04.11.2010.

Approved by the Advisory Board and accepted for publication on 16.11.10.

* Work conducted at Tropical Medicine Foundation of Amazonas (Fundação de Medicina Tropical do Amazonas - FMTAM) - Manaus (AM), Brazil. Conflict of interest: None / Conflito de interesse: Nenbum

Financial funding: None / Suporte financeiro: Nenbum

Undergraduate Degree in Pharmacy - Pharmacist-biochemist; M.Sc. student in infectious and parasitic diseases, Tropical Medicine Foundation of Amazonas (Fundação de Medicina Tropical do Amazonas - FMTAM) - Manaus (AM), Brazil.

Pharmacy student - Research initiation scholarship holder, Tropical Medicine Foundation of Amazonas (Fundação de Medicina Tropical do Amazonas - FMTAM) - Manaus (AM), Brazil.

Ph.D. in biotechnology - Researcher, Tropical Medicine Foundation of Amazonas (Fundação de Medicina Tropical do Amazonas - FMTAM) - Manaus (AM), Brazil. Ph.D. - Professor of Dermatology, University of the State of Amazonas (Universidade do Estado do Amazonas) - FMTAM - Manaus (AM), Brazil.

Ph.D. in dermatology - President of the Tropical Medicine Foundation of Amazonas (Fundação de Medicina Tropical do Amazonas - FMTAM) - Manaus (AM), Brazil

Ph.D. in immunology - Immunology Service, Hospital Universitário Prof. Edgard Santos (HUPES) and Department of Bio-interaction, Institute of Health Sciences, Federal University of Bahia (Universidade Federal da Bahia - UFBA); National Institute of Science and Technology in Tropical Diseases (Instituto Nacional de Ciência e Tecnologia de Doenças Tropicais - INCT-DT) - Salvador (BA), Brazil 


\section{INTRODUCTION}

The leishmaniases are neglected diseases that cause a burden of about two million DALYs worldwide. ${ }^{1}$ Ninety percent of all cases of tegumentary forms of these disorders concentrate in five countries, including Brazil, where approximately twenty thousand new cases of American tegumentary leishmaniasis (ATL) occur every year. ${ }^{2,3}$ The Amazon region corresponds to approximately $40 \%$ of these ATL cases, with Leishmania guyanensis as the most prevalent parasite. ${ }^{4-6}$ There are no previous studies that specifically address how a combination of diagnostic procedures improves case management in areas affected by ATL with high prevalence of this Leishmania species. In order to help fill this gap, we carried out a prospective study that enrolled 180 ATL patients, all amastigote-positive by the direct microscopic examination of specimens from lesion scarifications. The research was conducted at the Tropical Medicine Foundation (FMTAM) in Manaus, capital city of the state of Amazonas and one of the largest cities in the country, with 2.5 million inhabitants. FMTAM drains over $70 \%$ of all cases of ATL in the state of Amazonas, which is responsible for over $15 \%$ of the infections in the entire Brazilian Amazon region. ${ }^{4}$

\section{METHODS}

One hundred and eighty consecutive cases of ATL, confirmed by direct microscopic examination of giemsa-stained specimens from lesion scarifications, were enrolled.

\section{RESULTS}

There were 141 (78\%) males and 39 (22\%) females in the sample. Their ages varied from 5 to 65 , with a mean age of 29 years. Inclusion criteria consisted of any individual with confirmed infection, fewer than six lesions, willing to participate in the study and signing the informed consent form. Exclusion criteria consisted of current or recent (less than 90 days) treatment with anti-Leishmania drugs, treatment with immune system suppressive drugs, pregnancy and/or reported chronic conditions that might interfere with immunity against the parasite and thus bias their detection, like diabetes mellitus, AIDS and cancer. Histopathology, cultivation of parasites in LIT/NNN and Leishmania viannia specific PCR with discrimination between $L$. braziliensis and L. guyanensis, evaluating two different genomic targets (i.e. HSP-70 and mini-exon loci), were performed for lesion biopsy specimens of all subjects, following protocols previously reported. ${ }^{7-10}$

Table 1 summarizes the results obtained for each of the procedures and for several combinations of them. ${ }^{7.9}$ While the traditional and widespread meth- ods of parasite cultivation and lesion biopsy histopathology proved capable of detecting only half of the infections each, their combination improved sensitivity and allowed for detection of approximately three quarters of the infected ATL patients. The single most sensitive technique was PCR, which detected almost ninety percent of all infections, when the two tested amplification protocols (i.e. using primers for mini-exon and HSP-70) were employed. PCR had the same sensitivity as the combination of parasite cultivation and biopsy histopathology when only HSP-70 specific primers were used. The mini-exon protocol was employed only as a rescue protocol to detect infection and differentiate species in those samples that were negative for HSP-70 PCR. In these cases, the mini-exon specific PCR presented a sensitivity of $54 \%$. A combination of HSP-70 and mini-exon PCR protocols with parasite cultivation resulted in no improvement, while their combination with biopsy histopathology increased diagnostic sensitivity to $94 \%$. Besides having the highest sensitivity of all procedures, PCR also carries the advantage of allowing for species discrimination. In the current sample, 152 subjects were positive for $L$. guyanensis and 9 for $L$. braziliensis of the 161 patients with positive PCR. This indicates that the prevalence of human infections with $L$. guyanensis is $94 \%$ and prevalence of infections with $L$. braziliensis is $6 \%$ in the region of influence of FMTAM.

\section{DISCUSSION}

The data here reported show that PCR is a very sensitive procedure for confirming clinical suspicion of ATL, which could be easily implemented within secondary and tertiary health care units in L. guyanensisprevalent areas. In these diagnostic stances, PCR should be coupled with direct microscopic investigations of giemsa-stained scraping or impression smears and biopsy histopathology. Since diagnosis by all these techniques can be accomplished within twenty four hours of patients' initial consultations, antiLeishmania specific treatment might be rapidly initiated for positive patients. Negative cases would then undergo differential diagnosis for other causes of skin disease with clinical features overlapping ATL and further leishmaniasis investigation by specimen cultivation in LIT/NNN. However, cultivation takes weeks for detecting infection and presents lower sensitivity than PCR or its combination with histopathology.

The enrollment of patients with positive direct microscopic examination of skin scrapes in this study served the purpose of minimizing false diagnosis, while allowing for better comparison of top sensitivities for each test and their combinations in detecting 
TABLE 1: Sensitivities of different procedures used in the diagnosis of ATL

\begin{tabular}{lll}
\hline Procedures & Numbers of positive cases* & Percentage of positive cases* \\
\hline Parasite cultures & 93 & $52 \%$ \\
Biopsy histopathology & 90 & $50 \%$ \\
PCR 1 (HSP-70) ${ }^{*}$ & 135 & $75 \%$ \\
PCR 2(HSP-70, mini-exon) ${ }^{+}$ & 161 & $89 \%$ \\
Culture + histopathology & 130 & $72 \%$ \\
PCR2 + culture & 164 & $91 \%$ \\
PCR 2 + histopathology & 170 & $94 \%$ \\
PCR + culture + histopathology & 170 & $94 \%$ \\
\hline
\end{tabular}

Patients that were positive for more than one technique in the assessment of combinations were counted only once.

\& - PCR protocol using primers specific for HSP-70 locus ${ }^{7,8}$

+ - Separate PCR protocols using primers specific for HSP-70 ${ }^{7,8}$ and mini-exon loci ${ }^{9}$

ATL in areas with high endemicity for L. guyanensis. However, the sensitivities here reported must be expected to drop markedly when cases which are negative by direct microscopic examinations are considered. It is also possible that evaluations of patients, testing positive and negative for Leishmania spp by direct microscopic examinations, result in correction of the prevalences here observed between the two species. This would be expected if their amastigote frequencies in lesions proved different.

There are several reported protocols of conventional PCR for detecting Leishmania $s p p{ }^{10}$. Some explore the nuclear genome of these parasites, other take advantage of the high copy number of kDNA mini-circles in the kinetoplast of these protozoa to heighten the sensitivity of the test. ${ }^{7-9}$ One such assay has been evaluated for its ability to detect L. guyanensis. ${ }^{11}$ Although the kDNA PCR proved highly sensitive, approaching $100 \%$ in that study, the sample was comprised of only 35 ATL patients. Furthermore, all subjects were culture positive for the parasite, which may have biased the results towards increased sensitivity.
However, the major drawback of that technique for day-to-day application is that it does not allow species identification.

\section{CONCLUSION}

The two protocols tested in the current study combine good overall sensitivity with the ability of discriminating species. This last feature is of great importance in the Amazon region because part of the infections will be due to $L$. braziliensis, which leads to aggressive mucosal involvement more often than other Leishmania. Furthermore, L. guyanensis and $L$. braziliensis present different sensitivities to the drugs used for treating ATL. Thus, adding these PCR procedures to the regular diagnostic steps would not only help increase detection of ATL, but also improve its management. For example, patients with $L$. braziliensis would undergo immediate detailed investigation for mucosal lesions and be advised of returning for eventual reassessments of mouth, throat and nose involvement, while L. guyanensis infected individuals might be straight put to pentamidine treatment, since this species is less sensitive to antimonials. ${ }^{12,13}$ 


\section{REFERENCES}

1. Mathers CD, Ezzati M, Lopez AD. Measuring the burden of neglected tropical diseases: the global burden of disease framework. PLoS Negl Trop Dis. 2007;1:e114.

2. Desjeux P. Leishmaniasis: current situation and new perspectives. Comp Immunol Microbiol Infect Dis. 2004;27:305-18.

3. Lindoso JA, Lindoso AA. Neglected tropical diseases in Brazil. Rev Inst Med Trop Sao Paulo. 2009;51:247-53.

4. Datasus.gov [Internet]. Brazilian Ministry of Health, DATASUS. [cited 2010 0ct 28]. Available from: http://www.datasus.gov.br.

5. Lainson R, Shaw JJ, Silveira FT, de Souza AAA, Braga RR, Ishikawa EAY. The dermal leishmaniases of Brazil, with special reference to eco-epidemiology of the disease in Amazonia. Mem Inst Oswaldo Cruz. 1994;89:435-43.

6. Penna G, Pinto LF, Soranz D, Glatt R. High incidence of diseases endemic to the Amazon region of Brazil, 2001-2006. Emerg Infect Dis. 2009;15:626-32.

7. Garcia L, Kindt A, Bermudez H, Llanos-Cuentas A, De Doncker S, Arevalo J, et al. Culture-independent species typing of neotropical Leishmania for clinical validation of a PCR-based assay targeting heat shock protein 70 genes. J Clin Microbiol. 2004; 42: 2294-2297.

8. Montalvo AM, Fraga J, Monzote L, Montano I, De Doncker S, Dujardin JC, et al. Heatshock protein 70 PCR-RFLP: a universal simple tool for Leishmania species discrimination in the New and Old World. Parasitology. 2010;137:1159-68.

9. Marfurt J, Nasereddin A, Niederwieser I, Jaffe CL, Beck HP, Felger I. Identification and differentiation of Leishmania species in clinical samples by PCR amplification of the miniexon sequence and subsequent restriction fragment length polymorphism analysis. J Clin Microbiol. 2003;41: 3147-53.
10. Goto $\mathrm{H}$, Lindoso JA. Current diagnosis and treatment of cutaneous and mucocutaneous leishmaniasis. Expert Rev Anti Infect Ther. 2010;8:419-33.

11. Romero GA, Guerra MV, Paes MG, Cupolillo E, Bentin Toaldo C, Macêdo VO, et al. Sensitivity of the polymerase chain reaction for the diagnosis of cutaneous leishmaniasis due to Leishmania (Viannia) guyanensis. Acta Trop. 2001;79:225-9.

12. Arevalo J, Ramirez L, Adaui V, Zimic M, Tulliano G, Miranda-Verástegui C, et al. Influence of Leishmania (Viannia) species on the response to antimonial treatment in patients with American tegumentary leishmaniasis. J Infect Dis. 2007;195:1846-51.

13. Lima EB, Porto C, Motta JOC, Sampaio RNR. Tratamento da leishmaniose tegumentar americana. An Bras Dermatol. 2007;82:111-24.

ENDEREÇO PARA CORRESPONDÊNCIA / MAILING ADDRESS: Carolina Talbari

Av. Pedro Texeira, 25, Dom Pedro CEP: 69050-085 - Manaus, AM E-mail address: carolinatalbari@gmail.com

Como citar este artigo/How to cite this article: Benício EA, Santos MCC, Oliveira CMC, Talhari C, Talhari S, Schriefer A, et al. Combining diagnostic procedures for the management of leishmaniasis in areas with high prevalence of Leishmania guyanensis. An Bras Dermatol. 2011;86(6):1141-4. 